\title{
Hydraulic forging presses - innovative solutions
}

\author{
Hydrauliczne prasy kuźnicze - innowacyjne rozwiązania
}

\section{RYSZARD DINDORF JAKUB TAKOSOGLU PIOTR WOŚ*}

The main purpose of the research is to develop and implement a breakthrough technology with the hot open die forging of heavy, hardly deformable forgings for Celsa Huta Ostrowiec (CHO) on 80 MN hydraulic forging presses using an innovative energy-saving power supply systems and an intelligent control system in real time. The results of the first stage of the project were presented, the purpose of which was to determine the predictive force of hot die open forging deformation in the lengthening process. Then, based on the simulation model, the time characteristics of the forging process were determined on a hydraulic forging press of $80 \mathrm{MN}$. Based on these results, the prediction system of manufacturing process of large-size forgings on a hydraulic forging press will be developed

KEYWORDS: hot open die forging, hydraulic forging press

Głównym celem badań jest opracowanie ì wdrożenie przełomowej technologii kucia matrycowego na gorąco ciężkich, trudno odkształcalnych odkuwek dla Celsa Huta Ostrowiec (CHO) na hydraulicznych prasach kuźniczych o nacisku 80 MN z zastosowaniem innowacyjnego, energooszczędnego systemu zasilania i inteligentnego systemu sterowania w czasie rzeczywistym. Przedstawiono wyniki pierwszego etapu projektu, w którym poszukiwano prognozowanej siły odkształcania kucia na gorąco w procesie wzdłużania. Następnie, posługując się modelem symulacyjnym, określono charakterystyki czasowe procesu kucia na hydraulicznej prasie kuźniczej o nacisku 80 MN. Na podstawie tych wyników zostanie opracowany system prognozowania procesu wytwarzania wielkogabarytowych odkuwek na hydraulicznej prasie kuźniczej.

SŁOWA KLUCZOWE: kucie swobodne na gorąco, hydrauliczne prasy kuźnicze

\section{Wprowadzenie}

Wraz z rozwojem przemysłu energetycznego i rosnącą mocą urządzeń energetycznych zwiększa się zapotrzebowanie na wielkogabarytowe elementy kute swobodnie na gorąco, z których wykonuje się m.in. wały turbin (wodnych, gazowych, parowych) czy wirniki generatorów elektrowni wiatrowych i gazowych. Kucie swobodne jest najstarszą metodą kucia. W ten sposób formuje się ciężkie materiały wsadów w krótkich seriach produkcyjnych. Odkuwki swobodnie kute znajdują nabywców głównie w przemyśle stoczniowym, maszynowym, energetycznym i hutniczym. Do kucia swobodnego ciężkich odkuwek stalowych (ze stali węglowych, stopowych, wysokostopowych, nierdzewnych i innych) wykorzystuje się wysokociśnieniowe hydrauliczne prasy kuźnicze.
DOI: https://doi.org/10.17814/mechanik.2019.11.102

W ciągu ostatnich 10 lat zbudowano na świecie kilkadziesiąt hydraulicznych pras kuźniczych o nacisku powyżej 100 MN (m.in.: Japan Steel Works 140 MN, South Korea Doosan 170 MN, China Shanghai 165 MN, Great Britain Sheffield Forgemasters $150 \mathrm{MN}$, Czech Republik Vítkovice 120 MN, Russia OMZ Izhora 150 MN). Wynika to głównie z zapotrzebowania na wielkogabarytowe wyroby kute w branży energii jądrowej i wiatrowej [2].

Największym i najbardziej znanym dostawcą ciężkich odkuwek jest Japan Steel Works (JSW). W JWS na prasach kuźniczych o nacisku 140 MN wytwarza się duże odkuwki do reaktorów jądrowych $(80 \%$ udział w rynku światowym), generatorów pary, wałów turbinowych i wałów napędowych statków. Prasa kuźnicza HBE Press (Korea) o nacisku 150 MN jest największa na świecie pod względem odległości między osiami kolumn (8 m), a druga pod względem tonażu (4200 ton). Krajowe kuźnie wykorzystują do kucia swobodnego na gorąco hydrauliczne prasy kuźnicze o nacisku od 8 do $82 \mathrm{MN}$.

W prasowni Zakładu Wyrobów Kutych Celsa Huta Ostrowiec (ZWK CHO) eksploatuje się trzy hydrauliczne prasy kuźnicze o nacisku 20, 32 i 80 MN (rys. 1). W ZWK $\mathrm{CHO}$ wytwarza się odkuwki o masie od kilkuset kilogramów do kilkudziesięciu ton ze stali konstrukcyjnych węglowych, nisko- i średniostopowych, głównie na potrzeby przemysłu energetycznego (wały napędowe turbin), okrętowego (wały korbowe i wały napędowe do silników statków), hutniczego (walce hutnicze), wydobywczego

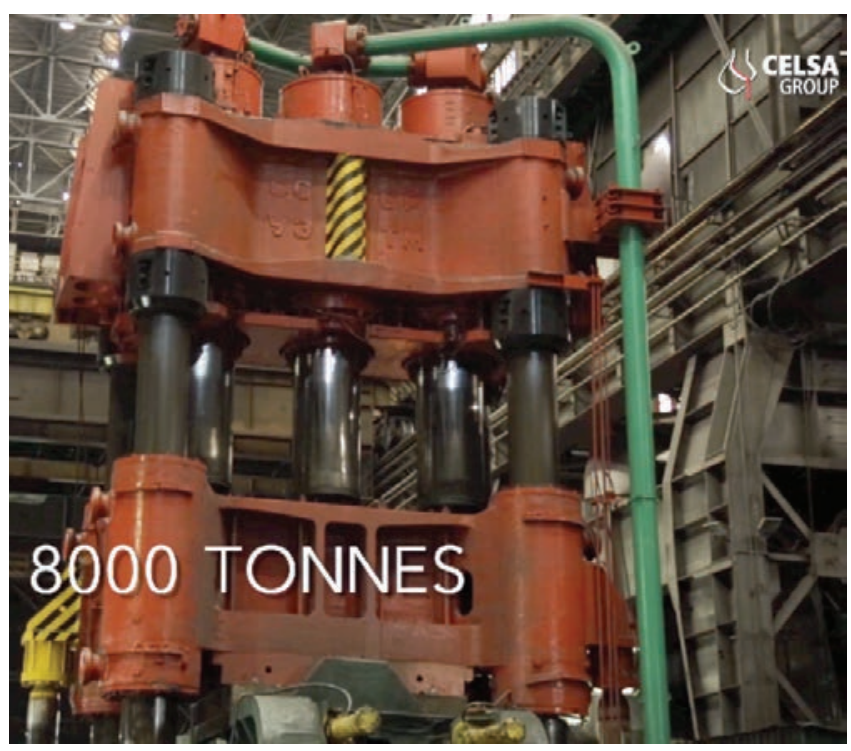

Fig. 1. Hydraulic forging press with the force of $80 \mathrm{MN}$, ZWK CHO Rys. 1. Hydrauliczna prasa kuźnicza o nacisku $80 \mathrm{MN}$ w ZWK CHO

\footnotetext{
* Prof. dr hab. inż. Ryszard Dindorf, dindorf@tu.kielce.pl, https://orcid.org/0000-0002-2242-3288 - Katedra Technologii Mechanicznej i Metrologii Wydział Mechatroniki i Budowy Maszyn, Politechnika Swiętokrzyska, Kielce, Polska

Dr Jakaub Takosoglu, qba@tu.kielce.pl, https://orcid.org/0000-0003-0606-039X - Katedra Technologii Mechanicznej i Metrologii, Wydział Mechatroniki i Budowy Maszyn, Politechnika Świętokrzyska, Kielce, Polska

Dr inż. Piotr Woś, wos@tu.kielce.pl, https://orcid.org/0000-0003-3107-366X - Katedra Technologii Mechanicznej i Metrologii, Wydział Mechatroniki i Budowy Maszyn, Politechnika Świętokrzyska, Kielce, Polska
} 
(pierścienie, cylindry, tuleje) i maszynowego (wały gładkie i wielostopniowe, pręty) [7]. W ZWK CHO produkuje elementy do turbin wiatrowych dla największych światowych dostawców (firm: Siemens, GE, Vestas, ACCIONA, Gamesa) oraz odkuwki do turbin energetycznych dużej mocy (m.in. dla firm: Alstom, Voith i Andritz).

$\mathrm{Na}$ rys. 2 pokazano materiał wsadowy (wlewek kuźniczy) do kucia swobodnego i produkt końcowy (wał napędowy). Na krajowym rynku ZWK CHO jest jedynym producentem odkuwek o dużych gabarytach: masie do 70 ton i długości do $23 \mathrm{~m}$. Poza tym najdłuższe odkuwki produkuje się w Kuźni Stalowa Wola (maksymalna długość $7 \mathrm{~m}$ i masa 10 ton). Inną wiodącą na rynku polskim kuźnią jest Kuźnia Glinik (należąca do grupy kapitałowej Polska Grupa Odlewnicza), której odkuwki mają maksymalną długość 4,5 $\mathrm{m}$ i masę 8 ton [6]
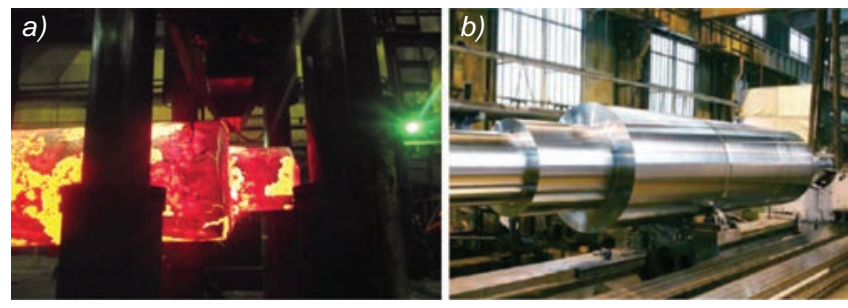

Fig. 2. Feedstock (ingot $-a$ ) and final product (drive shaft $-b$ )

Rys. 2. Materiał wsadowy (wlewka - a) i produkt końcowy (wał napędowy $-b$ )

Producenci odkuwek na rynku azjatyckim to m.in. KOBE Steel, Japan Steel Works, Mitsubishi Steel, Wuhan Forging Works, Hyundai, China First Heavy Industries, China Erzhong, South Korea Doosan. Producenci azjatyccy przeznaczają znaczną część swojej produkcji (ok. 70\%) na bardzo chłonny rynek wewnętrzny. Wśród konkurentów w branży wielkogabarytowych wyrobów kutych na rynku europejskim w pierwszej kolejności można wyróżnić producentów z Włoch (m.in.: Grupa GIVA, FMA, Ringmill, Luchini, Fomas, Monchieri). Silną pozycję mają też huty niemieckie (takie jak: Groeditz, Bohler Edelstahl, Deutsche Edelstahlwerke) oraz producenci z Czech, Francji i Wielkiej Brytanii.

\section{Układy zasilania wysokociśnieniowych pras kuźniczych}

Największe światowe firmy mają w swoich programach produkcyjnych innowacyjne, energooszczędne rozwiązania układów zasilających hydraulicznych pras kuźniczych: - Firma Wepuko PAHNKE (Niemcy) oferuje system PMSD (Pahnke Modifizierter Sinus Direktantrieb) - zmodyfikowany sinusowy napęd bezpośredni do olejowych układów hydraulicznych pras kuźniczych. W napędzie PMSD siłownik główny jest sterowany bezpośrednio przez serwosterowane pompy o zmiennej wydajności, bez rozdzielaczy w przewodach głównych. Umożliwia to precyzyjne sterowanie elementami ruchomymi, a także całkowicie bezwstrząsową pracę, co z kolei minimalizuje ryzyko nieszczelności i awarii przewodów oraz prasy. Najważniejszym składnikiem systemu PMSD jest pompa główna - wysoko wydajna wielotłoczkowa pompa promieniowa typu RX na maksymalne ciśnienie robocze $45 \mathrm{MPa}$. Wadą tego rozwiązania jest to, że nie można sterować naciskiem prasy w kilku operacjach.

- Firma OILGERS (Niemcy) oferuje rozwiązanie techniczne Transfer Barrier (TB) dla układu zasilającego prasy kuźniczej, polegające na zastosowaniu multiplikatorów nurnikowych olejowych lub wodnych. W tych układach nastawna pompa zasila multiplikator, w którym następuje transformacja energii z układu olejowego do układu wodnego zasilającego nurnik prasy kuźniczej. Zalety układu TB to m.in. zmienne natężenie przepływu pozwalające na zwiększenie prędkości cyklu prasy (kilkukrotne) oraz możliwość regulacji ciśnienia i zastosowania cieczy ekologicznych, wody czy cieczy HWBF (high water based fluid). Modułowa budowa umożliwia skonfigurowanie układu napędowego prasy, zmniejszenie zużycia energii o $15 \%$ w skali roku, wyeliminowanie akumulatorów do bezpośredniego zasilania nurnika prasy, osiągnięcie wysokiego ciśnienia użytecznego (do $65 \mathrm{MPa}$ ), zminimalizowanie pulsacji ciśnienia i zmniejszenie kosztów pracy prasy kuźniczej. System TB może zapewnić pożądane osiągi kucia w kilku etapach.

- Firma Hauhinco (USA) produkuje nurnikowe pompy do wysokociśnieniowej hydrauliki wodnej (wody, cieczy na bazie wody HWBF i cieczy z zawartością wody HWCF - high water containing fluids), np. pompa z serii EHP-5K $400 S$ osiąga maksymalnie: wydajność $540 \mathrm{l} / \mathrm{min}$, ciśnienie 420 barów, moc silnika 400 kW i prędkość obrotowa $1500 / 1800 \mathrm{obr} / \mathrm{min}$. Pompy tej firmy zastosowano w 2012 r. podczas modernizacji hydraulicznego układu sterowania prasy kuźniczej o nacisku 50000 ton w Cleveland, USA.

- Firma Inoxihp (Włochy) produkuje wysokociśnieniowe trójnurnikowe pompy z serii PF 480 pracujące na wodę i emulsje wodne. Pompy te są przeznaczone do układów zasilających stalowni i pras kuźniczych. Maksymalne parametry pompy z serii PF 480 to: ciśnienie $42 \mathrm{MPa}$, wydajność $434 \mathrm{l} / \mathrm{min}$, moc $350 \mathrm{~kW}$, prędkość obrotowa $1500 \mathrm{obr} / \mathrm{min}$. W przemyśle hutniczym produkty firmy Inoxihp zapewniają optymalne rozwiązania techniczne.

- Firma Schäfer \& Urbach (Niemcy) produkuje kompaktowe jednostki napędowe do pras kuźniczych oparte na pompach trójnurnikowych z serii PPW 200 o parametrach: $600 \mathrm{~kW}, 500$ barów, 2624 l/min, prędkość obrotowa $50 \div 275 \mathrm{obr} / \mathrm{min}$ i ze średnicami tłoka (nurnika) $\varnothing 70 \div 170 \mathrm{~mm}$. Dzięki kompaktowej konstrukcji jednostka napędowa ma mniejszą masę, przez co jest łatwiejsza do instalacji w warunkach przemysłowych. Jednostki napędowe z serii PPW 200 są bezpieczne w użytkowaniu i tanie w eksploatacji. Pompy te są przeznaczone do medium roboczego w postaci wody i emulsji oleju w wodzie, mają zasilać hydrauliczne prasy kuźnicze i inne urządzenia przemysłowe. Pompy z serii PPW 200 są wyposażone w rezonator bocznikowy do tłumienia pulsacji ciśnienia. Firma Schäfer \& Urbach dostarcza rozwiązania przystosowane do modernizowanych pras kuźniczych do kucia na gorąco, w tym do elektrohydraulicznych układów sterowania.

- Firma SMS MEER (Niemcy) produkuje m.in. prasy do kucia swobodnego oraz zintegrowane układy sterowania (wodne i olejowe) do pras i manipulatorów.

\section{Zasilanie i sterowanie wysokociśnieniowych pras kuźniczych}

Analizowano trzy innowacyjne rozwiązania zasilania wysokociśnieniowych pras kuźniczych.

\section{Rozwiązanie 1}

Pierwsze rozwiązanie przedstawiono na rys. 3. Proponowany układ zasilania pras kuźniczych musi spełniać następujące wymagania: zmniejszenie pulsacji ciśnienia i ograniczenie zjawiska uderzenia hydraulicznego; sterowanie naciskiem prasy dostosowanym do charakterystyki 


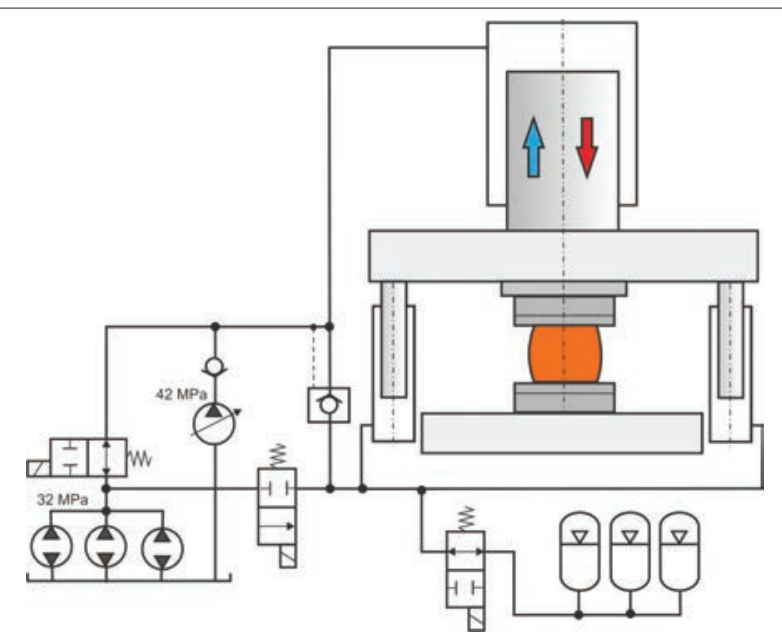

Fig. 3. Diagram of the hydraulic forging press supply according to solution 1

Rys. 3. Schemat zasilania hydraulicznej prasy kuźniczej według rozwiązania 1

kucia swobodnego na gorąco ciężkich odkuwek; ograniczenie zużycia energii podczas procesu kucia. Mając na uwadze ograniczenia dotyczące dostępności wysokociśnieniowych pomp wodnych i konieczności stosowania wody lub cieczy HWBF jako czynnika roboczego, można zaproponować innowacyjne rozwiązania, nigdzie dotychczas nie stosowane, polegające na wprowadzeniu dwóch równoległych obwodów zasilających:

- jednego - opartego na dotychczasowych rozwiązaniach z pompami trójnurnikowymi tłokowymi nieregulowanymi o parametrach średniego ciśnienia zasilania (32 MPa) i dużej wydajności (2000 l/min);

- drugiego - opartego na pompie promieniowej regulowanej o parametrach maksymalnego ciśnienia zasilania (42 MPa) i mniejszej wydajności (500 l/min).

Takie rozwianie pozwala zoptymalizować proces kucia, zwłaszcza ciężkich odkuwek, w kilku procesach wymagających różnej siły nacisku, a także umożliwia uzyskanie dokładnych wymiarów odkuwek przez wysokociśnieniowe dogładzanie.

\section{Rozwiązanie 2}

Zasilanie hydraulicznej prasy kuźniczej według drugiego rozwiązania przedstawiono na rys. 4. Zaproponowano napęd pompowo-multiplikatorowy $z$ dwoma multiplikato-

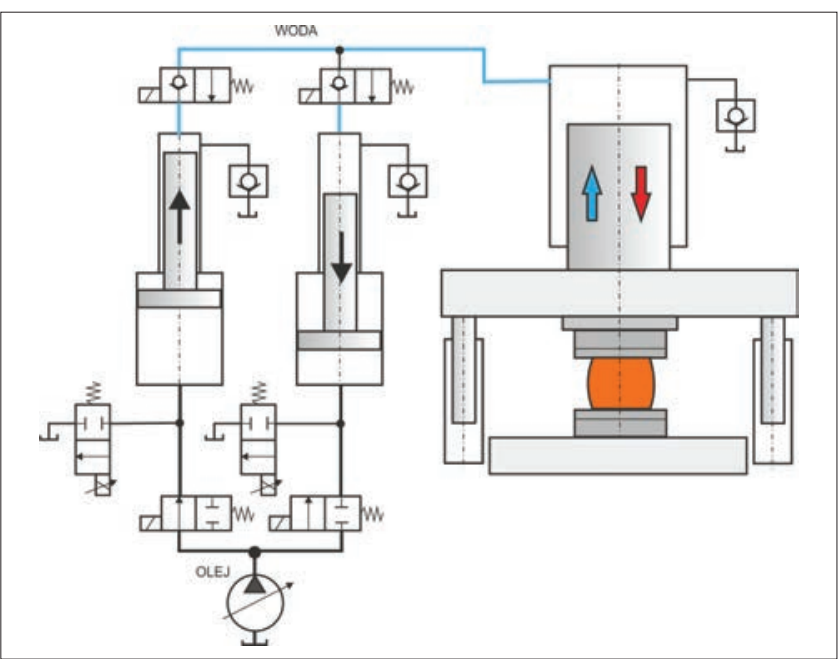

Fig. 4. Diagram of the hydraulic forging press supply - solution 2 Rys. 4. Schemat zasilania hydraulicznej prasy kuźniczej - rozwiązanie 2 rami nurnikowymi. Takie rozwiązanie łączy zalety napędu hydraulicznego olejowego i napędu hydraulicznego wodnego. W multiplikatorach występuje transformacja energii z regulowanego układu pompowego (układu olejowego) do układu wodnego zasilającego siłownik nurnikowy prasy. Pompa hydrauliczna jest zasilana klasycznym agregatem hydraulicznym olejowym, który daje duże możliwości sterowania parametrami hydraulicznymi. Zaletą napędu multiplikatorowego nurnikowego jest minimalna pulsacja ciśnienia, która ma duży wpływ na dokładność procesu kucia swobodnego. Znane są różne rozwiązania zasilania pras kuźniczych do kucia swobodnego za pomoca multiplikatorów, ale do sterowania układami zasilającymi pompowymi stosuje się klasyczne systemy ze sterownikami PLC. W tym projekcie zaproponowano innowacyjne rozwiązanie oparte na systemie sterowania czasu rzeczywistego.

\section{Rozwiązanie 3}

Zasilanie hydraulicznej prasy kuźniczej według trzeciego rozwiązania przedstawiono na rys. 5. Zaproponowano nowe wysokociśnieniowe pompy promieniowe z serwosterowaniem. To pompy o zmiennej objętości, pracujące w układzie sterowania objętościowego. Największa różnica w stosunku do zwykłych systemów sterowania napędów pras polega na tym, że prędkość robocza i kierunek ruchu pras są sterowane przez wielotłoczkowe pompy promieniowe, które nie potrzebują zaworów rozdzielających, jak na rys. 3 i 4 . Pompy z serwosterowaniem zasilają bezpośrednio siłownik nurnikowy hydraulicznej prasy kuźniczej, co powoduje mały spadek ciśnienia i maksymalną efektywność działania układu zasilającego. Energia generowana przez pompy hydrauliczne odpowiada na potrzeby technologicznej prasy kuźniczej. Dzięki takiemu rozwiązaniu można osiągnąć wysoką częstość cyklu roboczego i znaczne oszczędności energii. Główna zaleta tego systemu napędowego są niskie koszty eksploatacji.

Natomiast proponowane innowacyjne rozwiązania sytemu sterowania w czasie rzeczywistym procesem kucia na hydraulicznych prasach kuźniczych przedstawiono na rys. 6. Na podstawie znanego prognozowanego związku funkcjonalnego między siłą kucia $F_{\mathrm{h}}(t)$ a wysokością odkształcanej odkuwki $h(t)$ można oszacować przebieg odkształcenia odkuwki w czasie, aż do jej ostatecznego przekucia. Przedstawiona metoda umożliwia kształtowanie odkuwki za pomocą sterowania parametrami

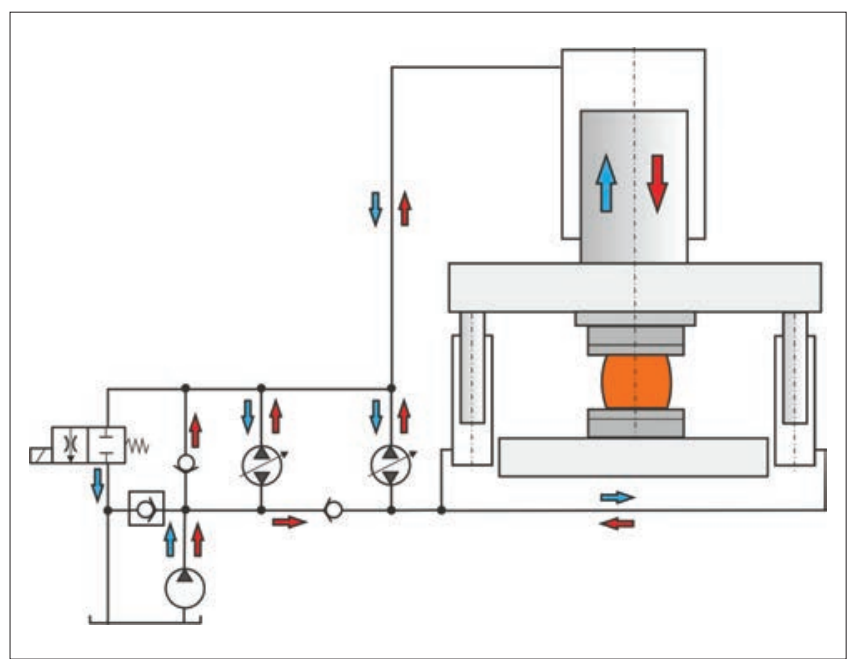

Fig. 5. Diagram of the hydraulic forging press supply - solution 3 Rys. 5. Schemat zasilania hydraulicznej prasy kuźniczej - rozwiązanie 3 


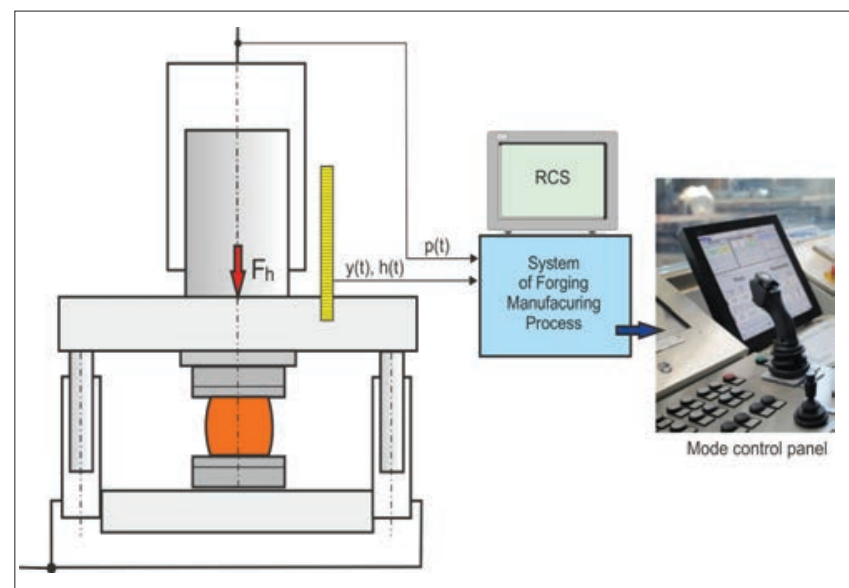

Fig. 6. Diagram of the proposed solution for the control system of the forging process on hydraulic forging press with the force of $80 \mathrm{MN}$

Rys. 6. Schemat proponowanego rozwiązania sytemu sterowania procesem kucia na hydraulicznych prasach kuźniczych o nacisku $80 \mathrm{MN}$

hydraulicznymi (ciśnieniem i natężeniem przepływu) w nurniku roboczym prasy poprzez regulację zaworami lub pompami zasilającymi. W sterowaniu tym można także uwzględnić wpływ sprężystości objętościowej (modułu ściśliwości) cieczy roboczej, przecieków w nurnikach prasy i innych parametrów na dokładność kucia swobodnego na gorąco wielkogabarytowych odkuwek.

\section{Model prognozowanej siły odkształcenia odkuwki}

Na rys. 7 przestawiono model swobodnego kucia na gorąco w procesie wydłużania, który posłużył do określenia prognozowanej siły odkształcenia odkuwki. Po przekuciu odkuwki zmniejsza się jej wysokość $z h_{0}$ do $h_{1}$, powstaje poszerzenie $z b_{0}$ do $b_{1}$ oraz wydłużenie $z l_{0}$ do $l_{1}$. Ogólny wzór prognozowanej siły odkształcenia $F_{\mathrm{p}}(h)$ odkuwki w przypadku kowadła płaskiego na prasie hydraulicznej w funkcji wysokości odkuwki $h$ ma postać:

$$
\begin{gathered}
F_{\mathrm{p}}(h)=K_{\mathrm{p}} A_{\mathrm{p}} \sigma_{\mathrm{p}}= \\
=k_{\mathrm{w}}\left(1+\frac{\mu_{s_{\mathrm{k} 1}}}{2 h}+\frac{h}{4 s_{\mathrm{k} 1}}\right)\left[s_{\mathrm{k} 0}+\left|\frac{\frac{h_{0} b_{0} s_{\mathrm{k} 0}}{h b_{1}}-s_{\mathrm{k} 0}}{1+\frac{1}{k}}\right|\right] b_{0}\left(\frac{h_{0}}{h}\right)^{a} \\
\cdot \sigma_{\mathrm{p} 0} \exp \left(-m_{1} T\right) \ln \left(\frac{h_{0}}{h}\right)^{m_{2}}\left(\frac{v}{h_{0}-h_{1}}\right)^{m_{3}} \exp \left(\frac{m_{4}}{\ln \left(\frac{h_{0}}{h}\right)}\right)
\end{gathered}
$$

gdzie:

$s_{\mathrm{k} 0}$ - początkowe odsunięcie odkuwki pod kowadłem, $K_{\mathrm{p}}$ - współczynnik oporu odkształcenia plastycznego według modelu Sibela [4],

$A_{p}$ - pole powierzchni odkuwki znajdującej się pod kowadłami [4],

$\sigma_{\mathrm{p}}$ - naprężenia uplastyczniające materiału odkuwki według modelu Hensel-Spittela [5],

$k_{\mathrm{w}}$ - współczynnik wzmocnienia odkształcenia,

$\mu$ - współczynnik tarcia,

a - stały wykładnik według wzoru Tomlinsona [3],

$\sigma_{\mathrm{p} 0}, m_{1}, m_{2}, m_{3}, m_{4}$ - współczynniki materiałowe określone z programu FORGE [4],

$T$ - temperatura odkuwki po zakończenia procesu kucia, $v$ - prędkość liniowa kucia - ruchu kowadła.

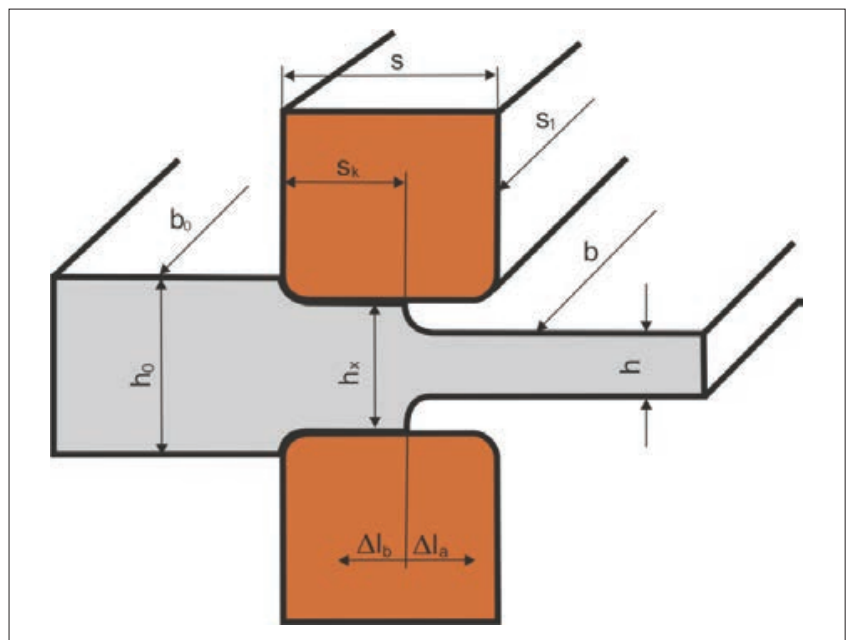

Fig. 7. Hot forging model in the elongation process Rys. 7. Model kucia na gorąco w procesie wydłużania

Wykresy prognozowanej siły $F_{p}$ odkształcania odkuwki dla różnych szybkości odkształcania i temperatury odkuwki przedstawiono na rys. 8-9.

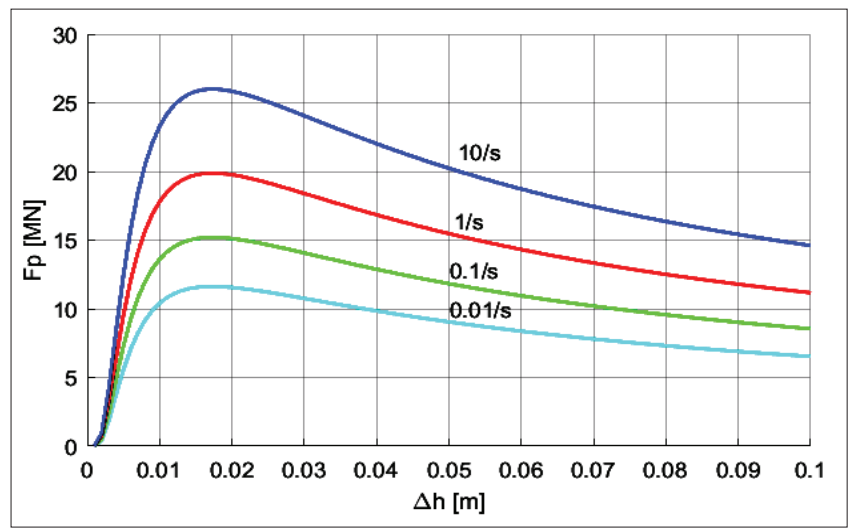

Fig. 8. Curves of the predicted deformation force $F_{p}$ of the forgings for different strain rates

Rys. 8. Wykresy prognozowanej siły odkształcania odkuwki $F_{\mathrm{p}}(\Delta h)$ dla różnych szybkości odkształcania

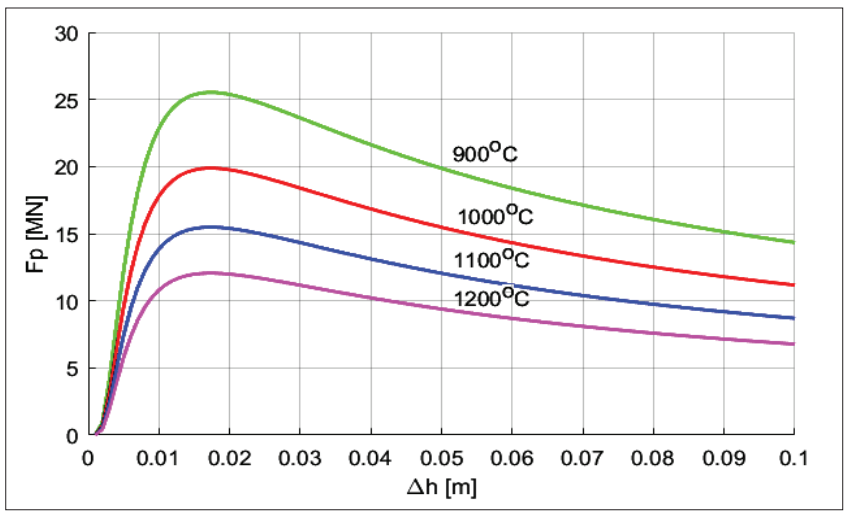

Fig. 9. Curves of predicted deformation force $F_{\mathrm{p}}$ of the forgings for different temperatures

Rys. 9. Wykresy prognozowanej siły odkształcania odkuwki $F_{p}(\Delta h)$ dla różnych temperatur odkształcania

\section{Model procesu kucia swobodnego na hydraulicznej prasie kuźniczej}

Schemat obliczeniowy hydraulicznej prasy kuźniczej o nacisku $80 \mathrm{MN}$, używanej do kucia swobodnego na gorąco ciężkich i wielkogabarytowych odkuwek, przedstawiono na rys. 10. Przeanalizowano dynamikę ruchu 


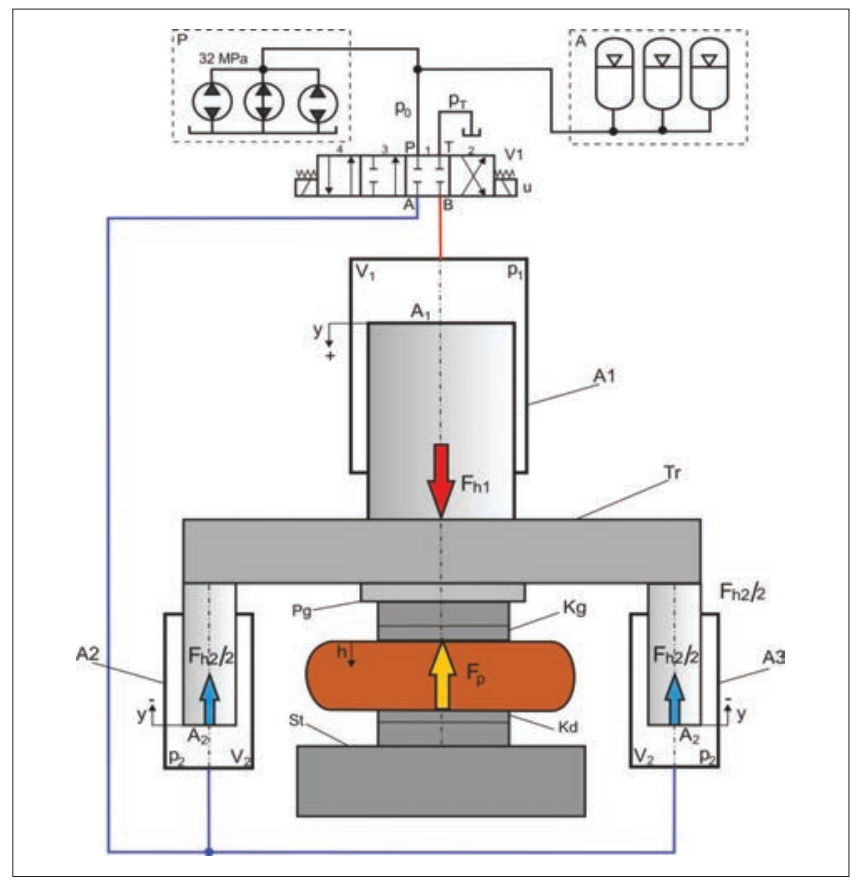

Fig. 10. Calculation model of a hydraulic press, $80 \mathrm{MN}$ : $A 1$ - working cylinder, $A 2, A 3$ - lifting cylinders, $V 1-4 / 4 /$ control valve, $P$ - pump station, $A$ - accumulators, $\operatorname{Tr}$ - movable traverse, $K g$ - upper die, $K d$ - bottom die, $P g$ - upper plate for fixing the upper anvil, $S t$ - table for fixing the bottom anvil

Rys. 10. Model obliczeniowy prasy hydraulicznej, $80 \mathrm{MN}$ : $A 1$ - cylinder roboczy, A2, A3 - cylindry podnoszenia, V1 - 4/4/zawór sterujący rozdzielający, $P$ - stacja pomp, $A$ - akumulatory, $\operatorname{Tr}$ - trawersa ruchoma $\mathrm{Kg}$ - kowadło górne, $\mathrm{Kd}$ - kowadło dolne, $\mathrm{Pg}$ - płyta górna do mocowania kowadła górnego, $S t$ - stół do mocowania kowadła dolnego

nurnika roboczego i nurników podnoszenia od momentu zetknięcia kowadła górnego z odkuwką; przyjęto następujące warunki początkowe: $y(0)=h_{0}$ oraz $\mathrm{d} y(0) / \mathrm{d} t=0$ :

- ruch roboczy "y+"

$$
\sum m \frac{\mathrm{d}^{2} y}{\mathrm{~d} t}+\sum b \frac{\mathrm{d} y}{\mathrm{~d} t}+\sum F_{\mathrm{t}}+F_{\mathrm{p}}=m g+F_{\mathrm{h} 1}-F_{\mathrm{h} 2}
$$

- ruch podnoszenia „y-”

$$
\Sigma m \frac{\mathrm{d}^{2} y}{\mathrm{~d} t}+\Sigma b \frac{\mathrm{d} y}{\mathrm{~d} t}+\Sigma F_{\mathrm{t}}+m g=F_{\mathrm{h} 2}-F_{\mathrm{h} 1}
$$

gdzie:

$\Sigma m$ - sumaryczna masa elementów ruchomych (nurnika roboczego, nurników powrotnych, trawersy ruchomej, płyty mocującej kowadła górnego),

$g$ - przyspieszenie ziemskie,

$a$ - przyspieszenie ruchu kowadła, $a=d^{2} y / d t^{2}$,

$v$ - prędkość ruchu kowadła, $v=\mathrm{d} y / \mathrm{d} t$,

$\Sigma F_{\mathrm{t}}$ - sumaryczna siła tarcia dla cylindra roboczego i cylindrów powrotnych,

$\Sigma b$ - sumaryczny współczynnik tarcia wiskotycznego dla cylindra roboczego i cylindrów powrotnych,

$F_{\mathrm{h} 1}$ - siła hydrostatyczna w cylindrze roboczym,

$$
F_{h 1}=\frac{\pi D_{1}^{2}}{4} p_{1}=A_{1} p_{1}
$$

gdzie:

$D_{1}$ - średnica nurnika roboczego, $A_{1}$ - powierzchnia nurnika roboczego, $F_{h 2}$ - siła hydrostatyczna w dwóch cylindrach powrotnych,

$$
F_{\mathrm{h} 2}=2 \frac{\pi D_{2}^{2}}{4} p_{2}=2 A_{2} p_{2}
$$

gdzie: $D_{2}$-średnica nurnika powrotnego, $A_{2}$ - powierzchnia nurnika powrotnego.

Równania ciśnienia w cylindrze roboczym i cylindrach powrotnych:

- ruch roboczy "y+"

$$
\left\{\begin{array}{l}
\frac{\mathrm{d} p_{1}}{\mathrm{~d} t}=\frac{K}{V_{1}}\left(A_{\mathrm{vBP}}(z) C_{\mathrm{d}} \sqrt{\frac{2}{\rho}} \sqrt{p_{0}-p_{1}}-A_{1} \frac{\mathrm{d} y}{\mathrm{~d} t}-k_{\mathrm{w} 1} p_{1}\right) \\
\frac{\mathrm{d} p_{2}}{\mathrm{~d} t}=\frac{K}{V_{2}}\left(-\frac{1}{2} A_{\mathrm{VAT}}(z) C_{\mathrm{d}} \sqrt{\frac{2}{\rho}} \sqrt{p_{2}-p_{\mathrm{T}}}+A_{2} \frac{\mathrm{d} y}{\mathrm{~d} t}-k_{\mathrm{w} 2} p_{2}\right)
\end{array}\right.
$$

- ruch podnoszenia „y-"

$$
\left\{\begin{array}{l}
\frac{\mathrm{d} p_{1}}{\mathrm{~d} t}=\frac{K}{V_{1}}\left(-A_{\mathrm{vBT}}(z) C_{\mathrm{d}} \sqrt{\frac{2}{\rho}} \sqrt{p_{1}-p_{T}}+A_{1} \frac{\mathrm{d}_{y}}{\mathrm{~d} t}-k_{\mathrm{w} 1} p_{\mathrm{l}}\right) \\
\frac{\mathrm{d} p_{2}}{\mathrm{~d} t}=\frac{K}{V_{2}}\left(\frac{1}{2} A_{\mathrm{vPA}}(z) C_{\mathrm{d}} \sqrt{\frac{2}{\rho}} \sqrt{p_{0}-p_{2}}-A_{2} \frac{\mathrm{d}_{y}}{\mathrm{~d} t}-k_{\mathrm{w} 2} p_{2}\right)
\end{array}\right.
$$

gdzie:

K - moduł ściśliwości czynnika roboczego (wody),

$V_{1}, V_{2}$ - objętości cylindra roboczego i cylindrów powrotnych,

$C_{\mathrm{d}}$ - współczynnik natężenia przepływu,

$A_{\text {vi }}(z)$ - przekrój kanału przepływowego zaworu w zależności od otwarcia zaworu $z$,

$k_{\mathrm{w} 1}, k_{\mathrm{w} 2}-$ stałe współczynniki przecieków zewnętrznych [1].

Model dynamiczny zaworu sterującego przyjęto w postaci członu inercyjnego pierwszego rzędu PT1, w którym iloczyn współczynnika wzmocnienia i sygnału wymuszającego wynosi $k_{\mathrm{z}}=K_{1} u$ :

$$
T_{1} \frac{\mathrm{d} z}{\mathrm{~d} t}+z=k_{\mathrm{z}} \Rightarrow \frac{\mathrm{d} z}{\mathrm{~d} t}=-\frac{1}{T_{1}} z+\frac{k_{\mathrm{z}}}{T_{\mathrm{l}}}
$$

gdzie: $T_{1}$ - stała czasowa członu inercyjnego pierwszego rzędu.

Dla parametrów wprowadzonych w modelu obliczeniowym przeprowadzono test symulacyjny w odniesieniu do zmiany wysokości odkuwki $\Delta h=0,1 \mathrm{~m}$ podczas jednego przykładowego gniotu i dla bieżącego stopnia przekucia $\lambda=1,4$. Wyniki testu pokazano na rys. $11-13$.

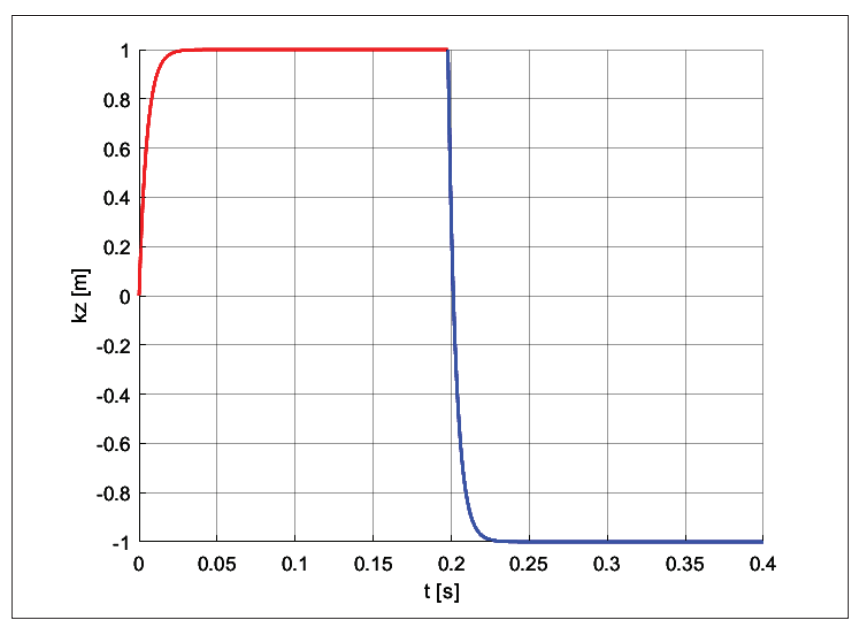

Fig. 11. Diagram of the degree of opening $k_{z}(t)$ of the control valve Rys. 11. Wykres stopnia otwarcia $k_{z}(t)$ zaworu sterującego 

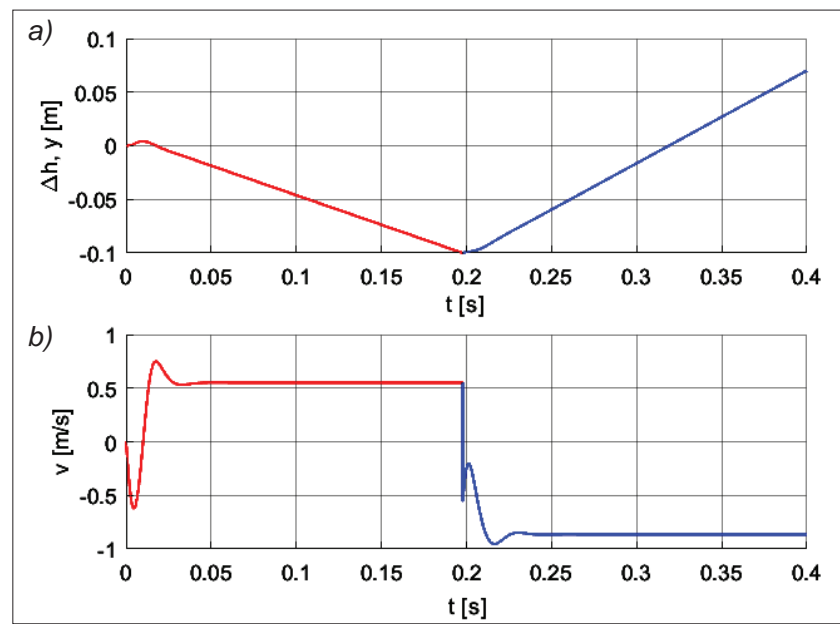

Fig. 12. Displacement $y(t)$ of the plunger in relation to the change in a) the forging height $\Delta h(t)$ and $b)$ speed $v(t)$ of the working plunger Rys. 12. Przemieszczenie $y(t)$ nurnika w odniesieniu do zmiany: a) wysokości odkuwki $\Delta h(t)$ oraz $b$ ) prędkości $v(t)$ nurnika roboczego
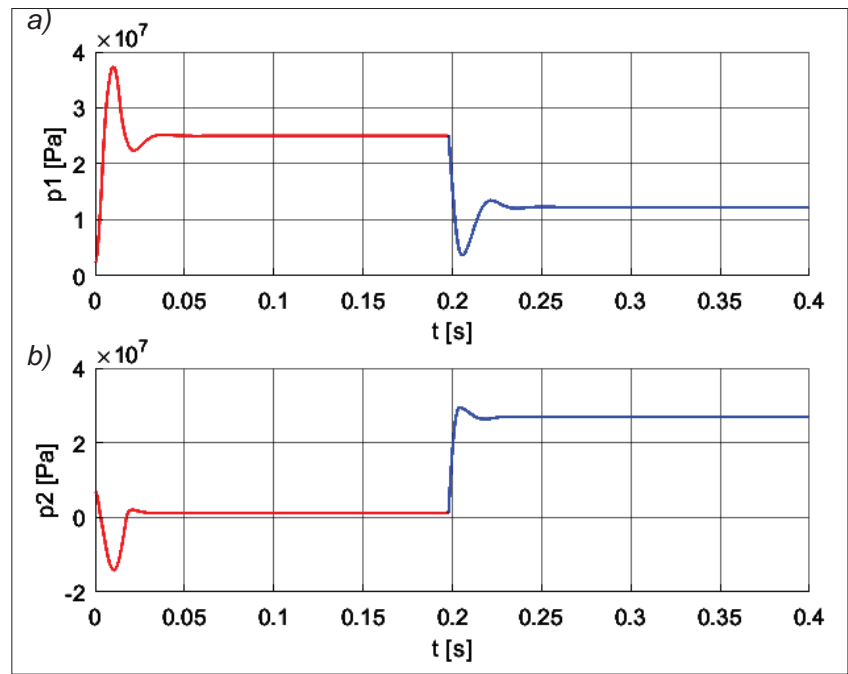

Fig. 13. Change in pressure $p_{1}(t)$ in the working cylinder $(a)$ and pressure $p_{2}(t)$ in the lifting cylinders $(b)$

Rys. 13. Zmiana ciśnienia $p_{1}(t)$ w cylindrze roboczym $(a)$ i ciśnienia $p_{2}(t)$ w cylindrach podnoszenia $(b)$

\section{Podsumowanie}

Celem projektu badawczego jest wdrożenie technologii kucia swobodnego na gorąco ciężkich, trudno odkształcalnych odkuwek na hydraulicznej prasie kuźniczej o nacisku $80 \mathrm{MN}$ z inteligentnym systemem sterowania w czasie rzeczywistym w prasowni ZWK CHO. Zastosowanie nowej technologii kucia i innowacyjnego systemu sterowania ma na celu optymalizację, zwiększenie efektywności energetycznej i zmniejszenie kosztów operacyjnych procesu kucia na gorąco.

Przedstawiono wyniki pierwszego etapu projektu, którego celem było określenie prognozowanej siły odkształcania odkuwki na gorąco w procesie wzdłużania na podstawie modelu naprężenia odkształceniowego z wartościami współczynników materiałowych wyznaczonymi w programie FORGE. Posługując się modelem symulacyjnym, określono charakterystyki czasowe procesu kucia na hydraulicznej prasie kuźniczej o nacisku 80 MN. Dla procesu kucia na gorąco odkuwek stalowych wielkogabarytowych na hydraulicznej prasie kuźniczej o nacisku 80 MN zostanie opracowany System Prognozowania Procesu Wytwarzania (SPPW), który będzie zawierał innowacyjny system sterowania w czasie rzeczywistym.
Praca została dofinansowana przez Narodowe Centrum Badań i Rozwoju (NCBR) w ramach projektu POIR.01.01.02-00-0163/16-00 nt. „Demonstracja technologii kucia swobodnego wielkogabarytowych odkuwek trudno odkształcalnych z zastosowaniem innowacyjnego energooszczędnego układu zasilania i inteligentnego sterowania prasami hydraulicznymi w czasie rzeczywistym", którego wykonawcą jest Celsa Huta Ostrowiec Sp. z o.o.

\section{LITERATURA}

[1] Dindorf R., Woś P. "Developments of hydraulic power systems". Monografie, Studia, Rozprawy M72. Kielce: Wydawnictwo Politechniki Świętokrzyskiej, 2016.

[2] Gregor M. "Forging. Didactic text". Ostrava: VŠB - TU Ostrava, 2014

[3] Knap M., Kugler G., Palkowski H., Turk R. "Prediction of material spreading in hot open-die forging". Steel Research International. 5, 2 (2004): 405-410, DOI: 10.1002/srin.200405787.

[4] Nötzel R.F. "Echtzeitprognose des Schmiedemaßes an hydraulischen Freiformpressen. Dissertation". Siegen: Universität Siegen, 2005, http://dokumentix.ub.uni-siegen.de/opus/volltexte/2006/197/.

[5] Opěla P., Schindler I., Kawulok P., Vančura F., Kawulok R., Rusz S., Petrek T. "Hot flow stress models of the steel C45". Metalurgija. 54, 3 (2015): 469-472, ISSN 0543-5846.

[6] Szyndler T. „Aktualny stan i trendy w kuźnictwie światowym i europejskim". Obróbka Plastyczna Metali. 3 (2006): 1-6, YADDA: bwmeta1. element.baztech-article-BPB2-0020-0001.

[7] Zdonek B., Szypuła I., Binek S., Kowalski J., Dudkiewicz P., Karbowniczek M., Barański J. „Innowacyjne rozwiązania w technologii produkcji wielkogabarytowych odkuwek z ultraczystych stali dla urządzen energetycznych". Prace IMŻ. 4 (2013): 53-59, YADDA: bwmeta1. element.baztech-5d66f46a-0641-4273-8eff-0b1528ba4cc4. 